20,936 received the full course of anti-rabic treatment, with a mortality of 0.45 per cent. The vaccino employed was a carbolized 5 per cent ernulsion of brain of sheep inoculated with Paris fixed virus. The deaths from rabies registered in 1937 in the Punjab and the United Provinces numbered 438 .

\section{Cosmic Data}

Two valuablo summaries of the data at present arailable as to the motion of the galactic system among tho nebula and as to the sources of stellar energy aro contributed by Dr. IS. Hubble, of the Mount Wilson Observatory, Pasadena, and by Prof. II. N. Russell, director of tho P'rinceton University Observatory respectively, to tho August issue of the Journal of the Franklin Institute. With respect to the extragalactic nebula taken as framo of reference, tho galactic system is moving with a speed of tho order of 100-200 kilometres per second in the direction of the northern galactic latitudes. The sun is rotating about tho centro of the galaxy with a specd of the order of 275 kilometres per second in the galactic direction latitudo $0^{\circ}$, longitude $55^{\circ}$. The resultant is a speed of the order 300 kilometres per second in tho direction latitude $35^{\circ}$ north, longitude $55^{\circ}$. After pointing out that the reactions which provido the stars with their energy must be accompanied by a loss of mass, I'rof. Russell summarizes the recent work of Prof. H. A. 13ethe, of Cornell University, on the six steps by which the impact of four protons, that is, hydrogen atoms, on a carbon atom which acts as a catalyst lead to tho production of a helium atom. Owing to the diminution of mass involved in tho conversion, the process is capablo of supplying the sun's energy if its temperature is of the order 18-21 million degrees centigrado, that of Sirius at 22 million and that of $\gamma$ Cygni at 30 million, all of which temperatures aro in agreement with astrophysical observations.

\section{The National Central Library}

The twenty-third annual report of tho Executivo Committeo of the National Central Iibrary refers to the way in which development has been hampered by the absence of sufficient funds. The only depart. ment which is ablo to provido anything liko an adequato service is the Bureau of American Bibliography, recently established with tho aid of a generous grant from the Rockefeller Foundation. The two main sources of income have been, as in previous years, the grants of $£ 5,000$ from the Treasury and $£ 4,000$ from the Carnegio United Kingdom Trust. Of the 10,825 volumes added to the library, 7,203 were presented; $\mathbf{4 6 , 7 1 5}$ books wero issued to libraries and 11,968 to adult classes. Tho total number of outlier libraries is 135 , consisting of 113 special libraries, 19 Isondon borough libraries and 3 urban libraries, representing a stock of $4,201,000$ volumes, from which 11,361 books wero lent during the year. The regional library systems now cover the whole of Fngland and Wales, embracing 479 libraries. During tho year, 50,031 books were lent by libraries in regional systems to other libraries in their own system, and in addition 7,104 books wero lent to libraries outside their own regional area through the National Central Library. Of the 3,538 books lent to university libraries, 1,846 wero supplied by the National Central Library and its outliers, 1,536 by other university libraries, and 156 by foreign libraries. As against 508 books lent to libraries in 24 foreign countries, libraries in 16 foreign countries lont 283 books to libraries in the British Isles.

\section{Data of Seismology}

VALUABLE seismological data havo just been received from India (Government of India, Meteorological Department, Seismological Bulletin, July-Sept. 1938). This publication contains readings of tho seismograms received at the observatories of Agra, Bombay, Calcutta, Colombo, Dehra Dun, Hyderabad and Kodaikanal, together with non-instrumental reports. Readings from tho Indian observatories aro par. ticularly important for the determination of the epicentres of earthquakes removed from North America, Europo and Japan, where the majority of the earth's seismological stations are situated. The non-instrumental reports indicato tho occurrence of four local shocks in July, soven in August and six in September, some of which wero followed by aftershocks. Silchar, Lahoro and Kalat each roported shocks on two separate occasions.

\section{Earthquakes during June 1939}

Accondina to the Central Seismological Bureau at Strasbourg, 132 earthquakes were registered by seismographs or felt by people during Juno 1939. The most on any ono day was ten on June 4, and the least on any one day was one on June 25. Undoubt. edly tho strongest shock during Juno was that of Juno 22 on the Gold Coast, hrving an epicentre provisionally calculated to be $5 \cdot 7^{\circ} \mathrm{N}$., $0 \cdot 7^{\circ} \mathrm{WV}$. The noxt three in intensity were Juno 18, felt scale 7 (Rossi-Forel) at Costa Rica, Juno 5 with epicentre in tho Atlantic west of tho Azores, and Juno 8 with possible deep focus (130 km.) in the Islands of Samoa. Other shocks for which provisional epicentres could bo obtained wero Juno 3, 'Tananarivo (scalo 2); Juno 4, north-west Australia and Arizona; Juno 6, Algeria; Juno 12, Porto Rico; June 23, near Apia; Juno 24, two in California; Juno 27, Philippines; and June 29, Vrancea. During Juno the Fort de Franco station registered eight local tremors.

\section{New Fellows in Pure Research at Mellon Institute}

Dr. R. S. 'Tipson and Dr. Warner Carlson have been appointed fellows in tho Department of Research in Pure Chemistry in the Mellon Institute. I)r. Tipson was born in Derbyshiro in 1906. Ho was awarded the degree of B.Sc. of the University of Birmingham in 1927 and then engaged in research on the carbohydrates under Prof. IV. N. Hawortl. Later ho conducted an investigation, for the British Fmpire Cancer Campaign, on the preparation of tobacco tar and determination of its constituents. In 1929 he was appointed to a research fellowship in the department of industrial and celluloso chem. 